\title{
CAMBRIDGE لاصRNALS
}

Knowledge is no longer shelved

The Cambridge Journals Digital Archive contains more than 160 journals, more than 3 million pages and more than 8 million linked references. Knowledge is now more visible and more searchable than ever.
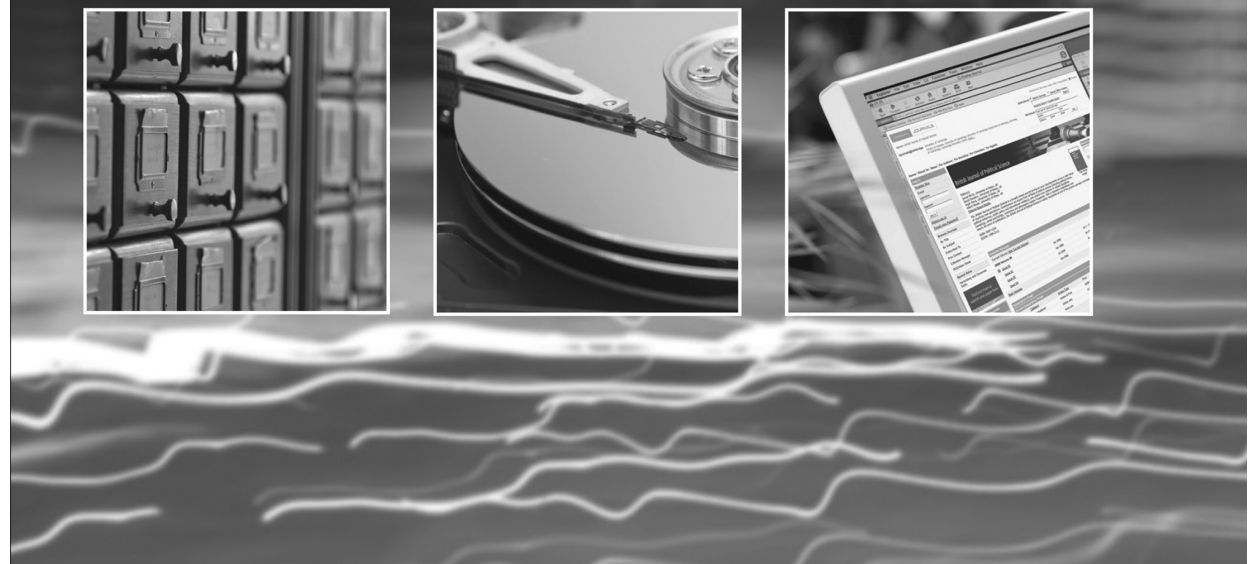

journals.cambridge.org/archives 


\section{Cambridge Journals Collections}

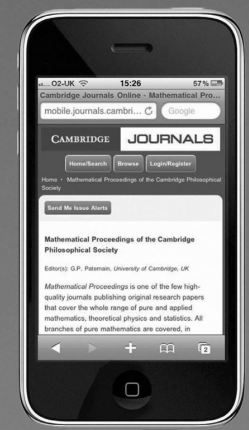

\section{Over 280}

leading titles online

As Complete Collection, HSS or STM

Via Cambridge Journals Online (CJO) or CJO Mobile (CJOm)

Please email:

jnlsales@cambridge.org for further info

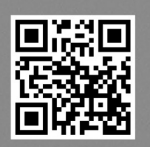

journals.cambridge.org

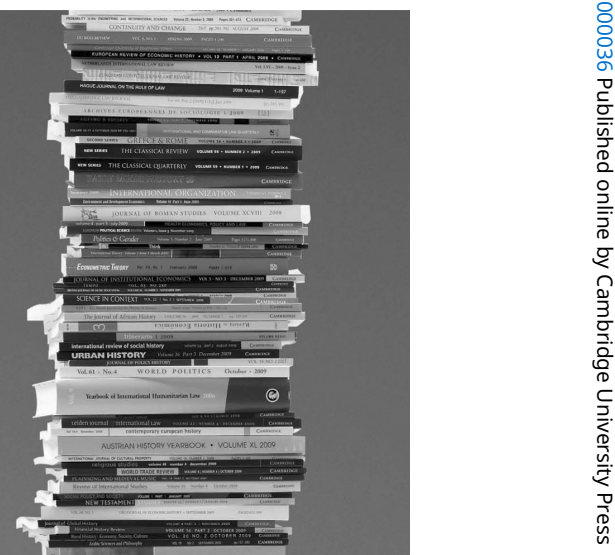




\section{Economics \& Philosophy}

\section{Editors}

Martin van Hees, University of Groningen, Netherlands James Konow, Kiel University, Germany and Loyola Marymount University, USA

Christian List, London School of Economics, UK

François Maniquet, CORE (Université Catholique de Louvain), Belgium

The disciplines of economics and philosophy each possess their own special analytical methods, whose combination is powerful and fruitful. Each discipline can be enriched by the other. Economics \& Philosophy aims to promote their mutual enrichment by publishing articles and book reviews in all areas linking these subjects. Topics include the methodology and epistemology of economics, the foundations of decision theory and game theory, the nature of rational choice in general, historical work on economics with a philosophical purpose, ethical issues in economics, the use of economic techniques in ethical theory, and many other subjects.

Economics \& Philosophy is available online at: http://journals.cambridge.org/eap

To subscribe contact Customer Services

in Cambridge:

Phone +44 (0)1223 326070

$\mathrm{Fax}+44(0) 1223325150$

Email journals@cambridge.org

in New York:

Phone +1 (845) 3537500

$\mathrm{Fax}+1(845) 3534141$

Email

subscriptions_newyork@cambridge.org

\section{Free email alerts}

Keep up-to-date with new material - sign up at

journals.cambridge.org/register

For free online content visit: http://journals.cambridge.org/eap 


\section{Instructions for Contributors}

\section{Contributions}

The journal publishes original academic research papers on the economics and finance of pensions, retirement income and ageing. The Journal also publishes "Issues and Policy" articles which review the state of knowledge or the debate in particular areas. Papers from actuarial science, mathematics, statistics and other disciplines are welcome as long as there is a clear economics or finance content. Examples of subjects the journal will cover include: pensions and labour markets, the macro- and micro-economics of pensions, pension fund management, regulation of pensions, valuation of pension liabilities, corporate governance, political economy issues, financial planning for retirement and marketing of private pensions.

\section{Manuscripts}

All manuscripts must be submitted online via the website:

\section{http://mc.manuscriptcentral.com/jpef}

Detailed instructions for submitting your manuscript online can be found at the submission website by clicking on the 'Instructions and Forms' link in the top right of the screen, and then clicking on the 'Author Submission Instructions' icon on the following page.

An Editor will acknowledge receipt of the manuscript, provide it with a manuscript reference number and assign it to reviewers. The reference number of the manuscript should be quoted in all correspondence with the JPEF Office and Publisher.

Manuscripts should begin with an abstract of not more than 100 words and ordinarily should not exceed 35 pages in length double spaced and 12pt font with 1 inch margins. Manuscripts will be reviewed by the editors and by referees chosen by the editors.

Manuscripts are accepted for review on the understanding that the same work has not been and will not be published nor is presently submitted elsewhere. While under editorial review, it is the responsibility of the authors to keep the Editors informed about submissions, publication plans, and actual publication of related research or abstracts thereof in other outlets, including letters, journals, review publications, journals in other disciplines, conference proceedings, and published dissertations. It is further understood that all persons listed as authors have given their approval for the submission of the paper and that any person cited as a source of personal communication has approved such citation; written authorization may be required at the Editor's discretion. Authors are responsible for obtaining written permission to publish material for which they do not own the copyright. Articles and other material published in Journal of Pension Economics and Finance represent the opinions of the authors and should not be construed to reflect the opinions of the Editors or their employers or the Publisher.

\section{Electronic submission of final manuscripts and illustrations}

A LaTeX class file is available. The JPEF class file and instructions are available by anonymous FTP from ftp://ftp.cup.cam.ac.uk/pub/texarchive/journals/latex/pef-cls/. LaTeX manuscripts should be accompanied by a pdf of the entire article so it can be printed out. The journal does not print in colour, so all figures should be black and white for reproduction.

\section{References}

The Harvard system of references should be used. Citations are by author's surname and year of publication, and may stand either as a noun phrase (e.g., "Diamond (1965)") or as a parenthetical note (e.g., "(Diamond 1965)"). List references at the end of the text in alphabetical order. A typical entry is: Diamond, P. (1965) National Debt in a Neoclassical Debt Model, Journal of Political Economy, 55 (December): 1126-1150.

\section{Offprints}

Authors will receive a pdf of their articles upon publication, and offprints may be ordered using the form sent out with proofs, provided that this is returned within fourteen days of receipt.

This journal issue has been printed on FSC-certified paper and cover board. FSC is an independent, non-governmental, not-for-profit organization established to promote the responsible management of the world's forests. Please see www.fsc.org for information. 


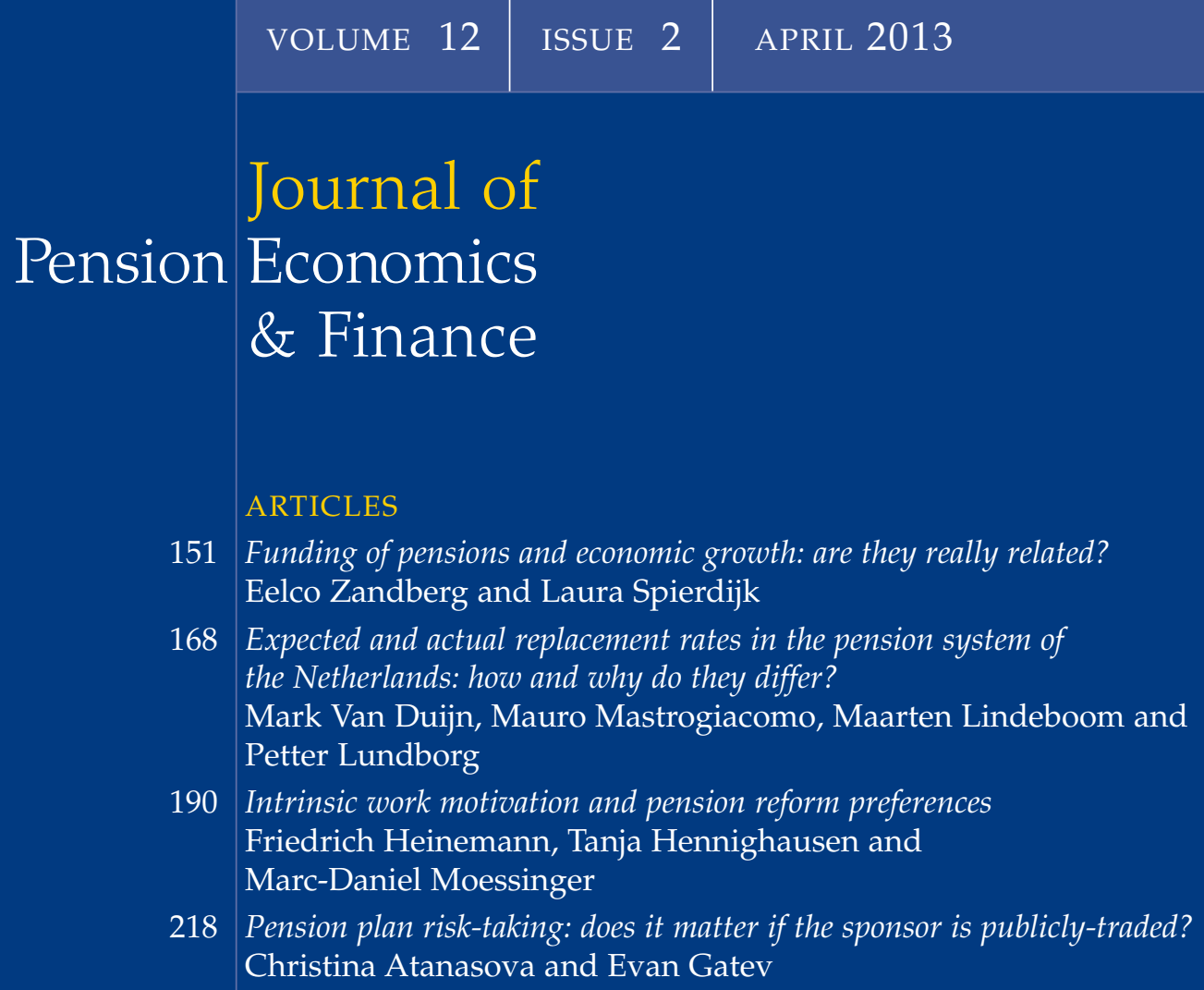

